\title{
Basic design in architectural education in Turkey
}

\author{
Elif Süyük Makaklı ${ }^{1}$ and Serpil Özker ${ }^{2 a}$, \\ ${ }^{1}$ Iş1k University, Faculty of Architecture and Design, Department of Architecture, Istanbul, 34980, \\ Turkey \\ ${ }^{2}$ Iş1k University, Faculty of Fine Arts, Department of Interior Architecture, Istanbul, 34398, Turkey
}

\begin{abstract}
Creative activity is one of the most significant parts of architectural education. In the architectural curriculum organisation 'design studio' is the unique and preeminent subject. Freshman students encounter 'design' first in basic design course, before they know what designing incorporates. The Basic Design is the starting point of initiating creativity in architecture education. It helps each student to understand architecture as a creative and innovative practice in the first year of education. This study analyzes the characteristics of basic design course, the topics of the course contents and its significance in the architectural curriculum in Turkey as well.
\end{abstract}

\section{Introduction}

In the rapidly changing and developing world, architects face different kinds of user demands in every aspect. Meeting these requests depends upon the architect's knowledge and experience. The institutions where the architects trained are the universities. In Turkey the first formal architectural education started within The Academy of Fine Arts in İstanbul in 1883, which is known firstly as "Sanayi-i Nefise Mekteb-i Alisi", while the presence of an architectural education's roots reach back to the 15th century, [13]. According to 2014 datas, there are totally 166 Universities in Turkey, 104 of them are State and the rest are foundation Universities, among them 122 have Architecture Schools, [11]. The assessment system for entry into University is based on a national university admission exam, taken in two parts by approximately 1.5 million students each year. Because of this multiple choice exams, the education system is generally criticized as being rote-learning oriented and accordingly freshman architectural students have limited previous experience in creative fields.

Design is the most important skill for an architect, therefore almost half of the architecture curriculum in a typical school dedicated to design. Architectural freshman students encounter 'design' first in basic design course, before they know what designing

\footnotetext{
${ }^{a}$ Corresponding author: serpil.ozker@isikun.edu.tr
} 
incorporates. The Basic design is the starting point of initiating creativity with a continuous research in architecture education which helps students to understand and feel the spatial perception. One of the objectives of this course is to create the right kind of platform for the students to start questioning and exploring by stimulating artistic sensitivity and creative powers. Architecture has never been one thing and an architect is expected to be equipped with artistic, scientific and social sensitivity. In basic design there is not unique correct or definitive answers, it is the studio of open questions. It does not impose any single design philosophy, but contrarily encourages the students to develop their perception and provide them bringing a particular approach to design. While developing analytical and abstraction abilities and providing creative and responsible solutions to unique and changing problems, the students start to understand architecture as a creative, productive, and innovative practice in the first year of education. It holds open the doors of discernment to the wide world of diversity and accordingly prevents the single-minded unity.

\section{Basic design course}

Architectural education concentrates on the open-ended, changing, contradictory and ambiguous character of architecture, which is interested in the unknown future, [16]. The National Architectural Accrediting Board (NAAB) In US lists 37 criteria that comprise a professional education in architecture. These criteria encompass three levels of accomplishment: ability, understanding and awareness, [8]. Among these are abilities in verbal and writing skills, graphic skills, research skills, critical thinking skills, fundamental design skills, etc. These criteria show that the multi-dimensional education is necessary, [4].

Architectural education is focused around the idea of a design studio. Design education is an intersection of technology, art and science, and design schools' curriculum reflects this multidiciplinary nature. Three basic aspects of design education is defined by Ledewitz, [10] as below:

1) learning and practising a number of new skills, such as visualization and representation,

2) learning a new language and

3) learning to think architecturally, [4].

Students face with all mentioned aspects for the first time in basic design course in the first year of architecture schools. Actually this course is instructed at all of art, design and architecture schools for freshmen students. 'Basic Design', is also called as 'Foundation Courses' or 'Enseignement Pre'liminaire', [1]. The main goal is to help students in developing conceptual ideas to bring elements of design into a whole and to make them familiar with the act of designing. This can be two or three dimensional, abstract or concrete.

Weimar Bauhaus (founded in 1918) considered as the first school, where a basic curriculum related to the education of creativity and basic design principles was executed. Moholy-Nagy defined the word Bauhaus as: "Bauhaus is a coined word. It means 'buildinghouse,' not only in a material, but also in a philosophic sense", [5].

Integration of all design disciplines which combines art and craft was the main philosophy of the school. The most important educational innovation at the Bauhaus was the development of the foundation or 'basic course' (Vorkurs) in design. According to this teaching, all design based disciplines need theoretically and practically an educational experience in "basic design concepts". Still many basic design course syllabi are based on the teaching developed in the Bauhaus school and other schools of the 20th century such as 
the Vhutemas, the School of Chicago and the School of Ulm (Hochschule Fur Gestaltung), [1]. Visual form is analyzed by Bauhaus teachers (Itten, Moholy-Nagy, Kandinsky and Klee) according to certain parameters such as; point, line, plane, color, texture, pattern, scale, and contrast. Visual organization of shapes and forms, in two and three-dimension are considered to be the main concerns of basic design. So two and three-D abstract compositions are widely used in this system. The founder Walter Gropius described his approaches in his book 'The New Architecture and the Bauhaus':

'Practical and formal subjects were taught side by side so as to develop the pupil's creative powers and enable him to grasp the physical nature of materials and the basic laws of design, [6].

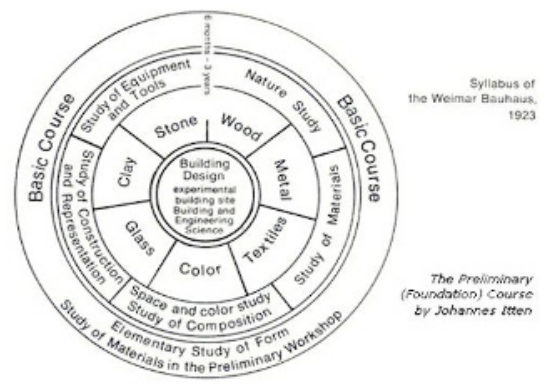

Fig.1. Syllabus of the Weimar Bauhaus.( http://www.artifexbalear.org/bauhaus.htm)

This approach has a lasting impact on design education around the architecture schools also in Turkey. Basic design courses are adapted from Bauhaus origin in which different fields of art and design were associated in an interdisciplinary manner, [12].

It aims to provide the students the fundamental skills and knowledge in order to understand the fundamentals of the architectural language. It helps to bring new perspectives and provide them a new type of learning and experience the world of space.

\section{Teaching-methods and-process}

Three main teaching models were described by Sprinthall and Sprinthall, [14]; teaching through transmission of knowledge, through discovery and inductive inquiry, and through interpersonal learning. In basic design course these three models are used but still learning design, through learning by doing is mostly applied, [4]. Teaching formats include lectures, studio workshops, individual presentations, and the "crit" or jury. In its nature, basic design education is mainly based on communication between students and instructors. By the critiques of the instructor and fellow classmates students have the opportunity to experience a variety of opinions about their work and to look from different point of views. They share their ideas to each other, participate actively and accordingly develop critical thinking. Through these critiques students take feedback about their works to improve them. Accordingly students have the opportunity to understand that there is not a single solution to a design problem and develop their designing skills within the framework of designing philosophies and theories, [7].

The design process is explored in various ways and contains many aspects of problem solving. Actually this education should be considered as an experimental process. The goal of the process is to gain the ability to reflect the products of perception and thought, [3]. 
Generally ill-defined problems are given which may have undefined goal and several alternative correct solutions are possible, [2]. Abstract problems help students to organize their thoughts and their design ideas. Learning design, through learning by doing is used in basic design education through studio activities and this process is often supported by lectures about related subjects.

Vesely, [15] mentions that, in architecture, the "key place for all educational activities is the studio." In studio working, thinking and learning should occur together. Learning often requires actual discovery by collaborative engagement of students and instructors in the learning process, [4]. The main requirement for a basic design course is to maintain a healthy communication with the instructor and the students in studios. Schon (1985) identified that learning in design studio begins with ill-defined problems, and learning in the studio developed through a process he named as 'reflection-in-action' Students use various techniques and materials to explore 2 and 3 dimensional thinking and perception in studio environment. Mostly class time is spent working on assignments in studios in this course but sometimes also an outside time can be needed to complete the work. A dynamic and experimental environment should be created, these places should be organised properly for increasing students' productivity. Spatial sizes of the studios should be enough for the number of students.

\section{Basic design education in Turkey}

According to 2014 datas, there are 122 Architecture Schools in Turkey. \% 60 of architecture schools are state and the rest are private universities. In the last decade total number of architectural students increased by $\% 155$, new registered students increased by $\%$ 240, [11]. The student quotas of 1937 in 2005 reached 5631 in 2013, [9].

In this study 20 universities are selected which 15 of them are state and the rest are foundation universities. The course hours, course load and its raito per term, its significance in the architectural curriculum, type of course are listed in Table 1.

Table 1. Architecture schools \& faculties in Turkey, basic design course hours, ects

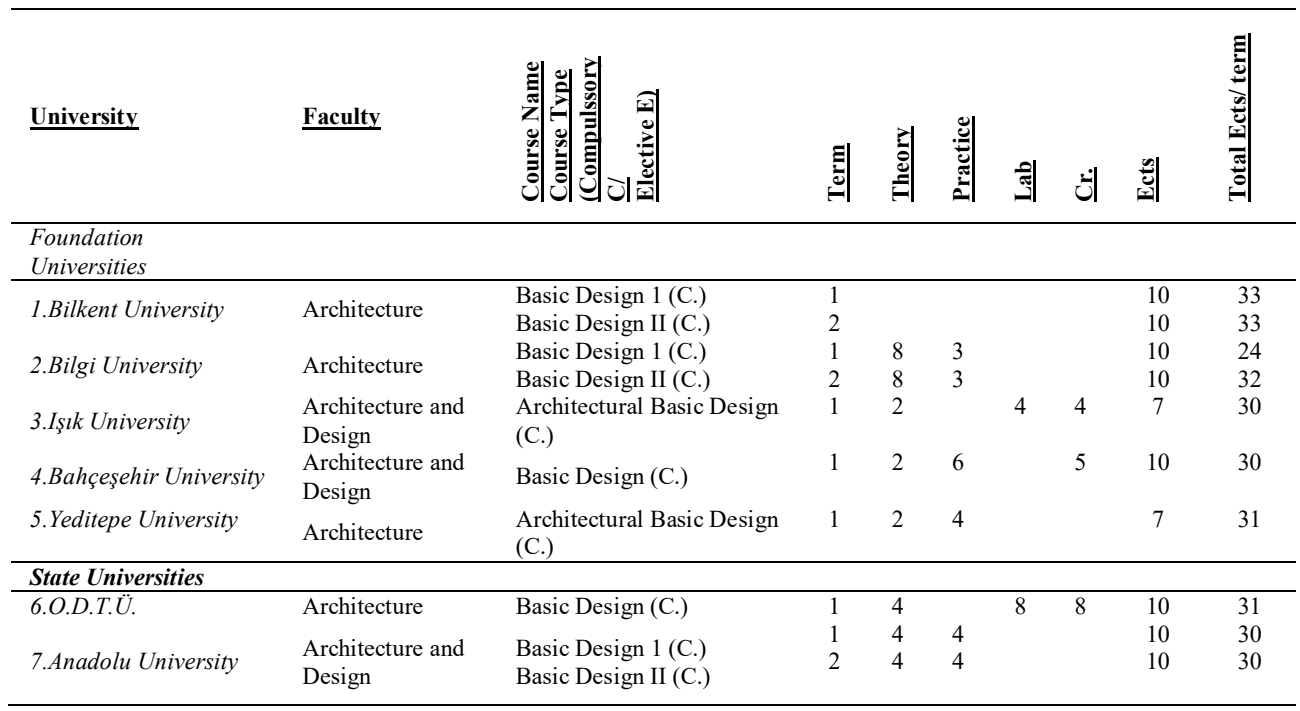


Table 1 continued. Architecture schools \& faculties in turkey, basic design course hours, ects

\begin{tabular}{|c|c|c|c|c|c|c|c|c|c|}
\hline University & $\underline{\text { Faculty }}$ & 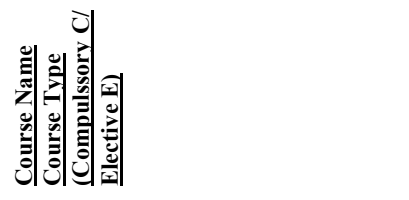 & 敬 & 或 & $\begin{array}{l}: \\
: \\
0 \\
0\end{array}$ & ज्ञึ & |تَّ & 㞵 & 绨 \\
\hline \multicolumn{10}{|l|}{$\begin{array}{l}\text { Foundation } \\
\text { Universities }\end{array}$} \\
\hline $\begin{array}{l}\text { 8. Yuldız Technical } \\
\text { University }\end{array}$ & Architecture & Basic Design (C.) & 1 & 1 & 2 & & 2 & 3 & 30 \\
\hline $\begin{array}{l}\text { 9. Istanbul Technical } \\
\text { University }\end{array}$ & Architecture & Basic Design and Visual Arts (C.) & 1 & 2 & 2 & & 3 & 6 & 32.5 \\
\hline 10.MSGSU & Architecture & $\begin{array}{l}\text { Basic Art And Design Education I (C.) } \\
\text { Basic Art And Design Education II (C.) }\end{array}$ & $\begin{array}{l}1 \\
2\end{array}$ & & $\begin{array}{l}4 \\
4\end{array}$ & & $\begin{array}{l}2 \\
2\end{array}$ & $\begin{array}{l}4 \\
4\end{array}$ & $\begin{array}{l}30 \\
30\end{array}$ \\
\hline $\begin{array}{l}\text { 11.Dokuz Eylül } \\
\text { Üniversitesi }\end{array}$ & Architecture & Basic Design (C.) & 1 & 4 & 4 & & 6 & 0 & 30 \\
\hline $\begin{array}{l}\text { 12.Gebze Technical } \\
\text { University }\end{array}$ & Architecture & Basic Design (C.) & 1 & 2 & 4 & & 4 & 7 & 30 \\
\hline 13.Gazi University & Architecture & Basic Design Studio (C.) & 1 & 2 & 4 & & & 8 & 30 \\
\hline $\begin{array}{l}\text { 14. İzmir Institute of } \\
\text { Technology }\end{array}$ & Architecture & Introduction to Design (C.) & 1 & 4 & 8 & & 4 & 12 & 30 \\
\hline 15. Trakya University & Architecture & $\begin{array}{l}\text { Basic Design } 1 \text { (C.) } \\
\text { Basic Design II (C.) }\end{array}$ & $\begin{array}{l}1 \\
2\end{array}$ & $\begin{array}{l}2 \\
2\end{array}$ & $\begin{array}{l}2 \\
2\end{array}$ & & $\begin{array}{l}3 \\
3\end{array}$ & $\begin{array}{l}5 \\
5\end{array}$ & $\begin{array}{l}29 \\
30\end{array}$ \\
\hline 16. Uludağ University & Architecture & $\begin{array}{l}\text { Basic Design } 1 \text { (C.) } \\
\text { Basic Design II (C.) }\end{array}$ & $\begin{array}{l}1 \\
2\end{array}$ & 1 & $\begin{array}{l}2 \\
2\end{array}$ & & $\begin{array}{l}3 \\
2\end{array}$ & $\begin{array}{l}4 \\
3\end{array}$ & $\begin{array}{l}30 \\
30\end{array}$ \\
\hline $\begin{array}{l}\text { 17.Çukurova } \\
\text { University }\end{array}$ & $\begin{array}{l}\text { Engineering } \\
\text { and } \\
\text { Architecture }\end{array}$ & $\begin{array}{l}\text { Basic Design } 1 \text { (C.) } \\
\text { Basic Design II (C.) }\end{array}$ & $\begin{array}{l}1 \\
2\end{array}$ & $\begin{array}{l}1 \\
1\end{array}$ & $\begin{array}{l}2 \\
2\end{array}$ & & $\begin{array}{l}2 \\
2\end{array}$ & $\begin{array}{l}4 \\
3\end{array}$ & $\begin{array}{l}30 \\
30\end{array}$ \\
\hline $\begin{array}{l}\text { 18. Ege University } \\
\text { 19.KTÜ }\end{array}$ & $\begin{array}{l}\text { Architecture } \\
\text { Architecture }\end{array}$ & $\begin{array}{l}\text { Basic Design (C.) } \\
\text { Basic Design (C.) }\end{array}$ & $\begin{array}{l}1 \\
1\end{array}$ & $\begin{array}{l}4 \\
2\end{array}$ & $\begin{array}{l}4 \\
4\end{array}$ & & & $\begin{array}{l}10 \\
6\end{array}$ & $\begin{array}{l}30 \\
30\end{array}$ \\
\hline $\begin{array}{l}\text { 20. Kocaeli } \\
\text { Uninversity }\end{array}$ & $\begin{array}{l}\text { Architecture } \\
\text { and Design }\end{array}$ & Basic Design (C.) & 1 & 4 & 2 & & 6 & 6 & 30 \\
\hline
\end{tabular}

Basic design education in the first year is named differently under various universities and faculties, though the purpose and application forms are similar.The course administered as a compulsory course in all selected universities during the 1 st or -and 2 nd semester of a four-year education. Datas indicate that in some of the selected universities, basic design courses are divided into two parts, practice and theory, and some of them are defined just within ECTS. The ECTS of basic design course has a considerable ratio in total ECTS of the term. During the semester, students practice on various assignments and sometimes as workshop training in order to improve their creative and practical thinking in a limited time. Courses are organized for a defined time in studios, mostly in syllabi timely attendance to the course is mentioned as a requirement.

In Education programs of the chosen architecture schools, the course curriculums include generally below topics: The design elements, which are the components or parts defined in any design; (1)Point, Line, Color, Form and Shape, Space, Texture, Value etc., (2)Visual and spatial perception; two and three dimensional concepts; (3)Visual Design Principles: Balance, Rhythm, Emphasis, Proportion, Repetition. In some schools, the course content is restricted to basic design elements and principles, in the others it includes architectural elements depending on the course hours, chosen approach and the kind of problems given. According to the educator's perspective and attitude the working methods are various, though the aim of the course is the same.

\section{Conclusion}

In architecture schools students should be prepared for the profession with necessary abilities and skills and have critical and creative thinking. As design discipline architecture is a highly visual and creative subject and students experienced this first in basic design 
course. It aims to provide the students the fundamental skills and knowledge needed for design education in order to understand the fundamentals of the architectural language. They develop a set of values and attitudes in geometrical, perceptual, and technological terms in this course. For the given problems there are not definitive answers and students have the opportunity to explore the properties of materials, colours, textures, and structures in the studio environment. Several techniques are used and these applied techniques are often closely related to the technical possibilities and the technology of that period. Since the basic design is an essential and significant part of architectural education, the course is administered generally as a compulsory course during the 1st or -and 2nd semester of a four-year education in Turkey which are generally impacted by Bauhaus approach. The language or method used in this first year course can be various according to the chosen approach. While in some schools, it is restricted to basic design elements and principles, in the others it includes architectural elements depending on the course hours, or on the chosen approach and the kind of problems given. In Basic Design education the technology of the time should be followed and technical facilities should be used in more effective way. In this sense, appropriate conditions must be ensured such as the spatial technological infrastructure and competent teaching staff. The objectives, the content and the methods of the course should be set carefully to develop student's sensitivity and should be organized in a way that motivate learning through discovery in order to develop their perception and provide them bringing a particular approach to design as open-minded individuals.

\section{References}

1. Adigüzel, Boucharenc, C.G., Research on Basic Design Education: An International Survey, International Journal of Technology and Design Education 16:1-30, (2006).

2. Casakin, H. \& Goldschmidt, G., Expertise and the use of visual analogy: Implications for design education. Design Studies, 20, 153-175, (1999).

3. Çetinkaya Ç., Basic Design Education Parameters In Turkey. Humanitas Number: 4,Autumn, Tekirdağ, (2014).

4. Farivarsadri G., A Critical View On Pedagogical Dimension Of Introductory Design In Architectural Education, AEE2001, (2001)

5. Findeli A., Moholy-Nagy's Design Pedagogy in Chicago (1937-46), Design Issues, Vol. 7, No. 1, Educating the Designer (Autumn), pp. 4-19, The MIT Press., (1990)

6. Gropius, W., 'The New Architecture and the Bauhaus', MIT Press., (1965).

7. Hacıhasanoğlu, O., Hacıhasanoğlu, I. \& Emer, Ö., Tasarım Stüdyosundaki Amaçlar. Ege Mimarlik, 3(47), 29-31, (2003).

8. ACSA, '1988 NAAB conditions and Procedures', ACSA News, May, pp5-7, (1988).

9. Küçükdoğu, M. Ş., Alioğlu, E. F., Dostoğlu, N., Esin, N, Türkçü H. Ç. , Coşgun, N., Enginöz, E. B., M. Arslan E., Mimarlık Bölümü Açılması ve Sürdürülmesinde Aranacak Asgari Koşullar Üzerine Bir Araştırma 1, Mimarlik, 374, 10-11, (2013).

10. Ledewitz, S., 'Models of design in studio teaching', Journal of Architectural Education, 38(2), pp 2-8, (1985),

11. Levi, E., Coşgun, A. \& Erkarslan N., Ö. E., Türkiye'de Mimarlık Eğitimine Niceliksel Bir Bakış, Mimarlik 381, 01-02, (2015).

12. Pasin, B., 'Sound-Object-Space: A Case Study on Utilizing Musical Composition for an Interdisciplinary Basic Design Education', 24th National Conference on the Beginning Design Student, (2008).

13. Sey, Y. \& Tapan, M., Architectural Education in Turkey: Past and Present.In Mimar 10: Architecture in Development, edited by Hasan-Uddin Khan. Singapore: Concept Media Ltd., (1983).

14. Sprinthall, R. \& Sprinthall, N. A., Educational Psychology: A Developmental Approach, Reading MA: Addison-Wesley, (1977). 
15. Vesely, D., "Back to School: Architectural Education - the Information and the Argument," AD: Architectural Design, 74(5), 63-66, (2004).

16. Yürekli İ. \& Yürekli, H., Mimari tasarım eğitiminde enformellik. İTÜdergisi/a Mimarlık, Planlama, Tasarım, Cilt:3, Sayı:1, 53-62, İstanbul, (2004).

17. Schön, D.A., The design studio: an exploration of its traditions and potentials RIBA Publications for RIBA Building Trust, London, (1985). 